\title{
The role of Fintech firms in contemporary financial sector development
}

\author{
INESE MAVLUTOVA, TATJANA VOLKOVA, AIVARS SPILBERGS, ANDRIS NATRINS, \\ ILJA AREFJEVS \\ BA School of Business and Finance \\ $161 \mathrm{Kr}$.Valdemara street, Riga \\ LATVIA
}

ATIS VERDENHOFS

Faculty of Engineering Economics and Management

Riga Technical University

6 Kalnciema street, Riga

LATVIA

\begin{abstract}
The development of new technologies provided by Information and communication technologies, robotics, artificial intelligence and their application have an essential influence on the business model of the financial sector companies. Changes are taking place through a variety of technology processes in different industries of the financial sector such as payment systems (including cryptocurrencies, smart chaining), customer acquisition and management, crowdfunding, P2P lending. The aim of the research is to study the role of Fintech firms in the changes in the financial sector landscape, as well dynamics of changes in investments in Fintech by regions and by segments. This study provides empirical evidence on the development of alternative financial services and their role in the development of the financial sector. Based on the research results there is strong evidence about statistically significant difference between investments allocated to Fintech firms by regions and vintage. There have been changes in the regional distribution of investment, with North America (85-90\%) dominating in the first years of the decade, and Asia and the Pacific accounting for more than a third and Europe for more than $20 \%$ of total investment in recent years. Contemporary statistics data analysis also indicates different trends in investments in various Fintech segments by years.
\end{abstract}

Key-Words: - financial sector, Fintech, Fintech firm, robotics, artificial intelligence, digitalization, Information and communication technologies

Received: August 13, 2020. Revised: December 29, 2020. Accepted: January 10, 2021. Published: February 2, 2021

\section{Introduction}

Although the term Fintech is widely used, a variety of interpretations for the term exists. The article focuses on the impact of financial technology development on the financial sector landscape, improving internal processes and providing new services to various actors in the financial sector.

Commercial banks compete fiercely with new financial market actors, e.g. financial technology start-ups or alternative financial institutions whose products and services overlap with those offered by banks and other financial institutions.

Financial technology start-ups or Fintech firms provide investment management or lending and savings services, financial advice, insurance, payment services, virtual currencies services. The traditional financial sector receives key support services (eg., big data, cloud, blockchain, customer identification and authentication services, internet of things etc.).

Although alternative financial institutions are widely represented in the financial markets, it is not fully studied yet what their direct and indirect role is in the development of the financial sector and changes in its landscape.

Nowadays Fintech firms are capable of providing financial services, which are more accessible and affordable to wider customer segments, in particular in the area of credits and payments [1]. Consequently, financial sector managers need to update competencies both on management and staff levels to deliver innovations to ensure sustainability of organizations in the short and long term based on latest available and upcoming technologies. Research methodology includes a systematic review 
of scientific literature, an analysis of the financial sector statistics as well as other methods.

\section{Theoretical background}

\subsection{The stages of financial technologies development}

Digital transactions in the financial sector began in the 1960s with the introduction of an innovative digital pricing system, which meant a shift from traditional systems to automated systems based on electronic communications. The integration of Information and communication technologies (ICT) that led to the use of the internet in business processes has revolutionized the relationships between companies and their stakeholders. ICT has also changed modern markets and radically transformed business models.

The Digital Banking report "Retail banking trends and predictions" [2] provides useful insights into contemporary developments, which put on the first place the use of data, artificial intelligence, and advanced analytics while customer experience was assessed to be the second big thing.

The evolution of the financial services development based on the impact of financial technologies leads to the changes of strategic focus of customer channels: from single customer channels to hybrid types of customer channels; the organization focus: from support processes, back offices, from offices, provider processes to customer processes; changes of systems focus towards higher level of systems integration. Table 1 summarizes the evolution of financial services development.
Table 1. Financial services industry digitization versus Financial technology

\begin{tabular}{|c|c|c|c|}
\hline $\begin{array}{l}\text { Phases } \\
\text { characteristics }\end{array}$ & $\begin{array}{l}\text { Strategy } \\
\text { focus }\end{array}$ & $\begin{array}{l}\text { Organization } \\
\text { focus }\end{array}$ & Systems focus \\
\hline $\begin{array}{l}\text { Phase 1: } \\
<1960\end{array}$ & $\begin{array}{l}\text { Single } \\
\text { customer } \\
\text { channel }\end{array}$ & $\begin{array}{l}\text { Support } \\
\text { processes }\end{array}$ & $\begin{array}{ll}\text { No } & \text { systems } \\
\text { integration } & \end{array}$ \\
\hline $\begin{array}{l}\text { Phase 2: } \\
1960-1980\end{array}$ & $\begin{array}{l}\text { Two } \\
\text { customer } \\
\text { channels }\end{array}$ & $\begin{array}{l}\text { Back-office } \\
\text { processes }\end{array}$ & $\begin{array}{l}\text { Partial internal } \\
\text { systems integration }\end{array}$ \\
\hline $\begin{array}{l}\text { Phase 3: } \\
1980-2010\end{array}$ & $\begin{array}{l}\text { Multi } \\
\text { customer } \\
\text { channel }\end{array}$ & $\begin{array}{l}\text { Front-office } \\
\text { processes }\end{array}$ & $\begin{array}{l}\text { Complete internal } \\
\text { systems integration }\end{array}$ \\
\hline $\begin{array}{l}\text { Phase 4: } \\
2010-2020\end{array}$ & $\begin{array}{l}\text { Cross } \\
\text { customer } \\
\text { channel }\end{array}$ & $\begin{array}{l}\text { Provider } \\
\text { processes }\end{array}$ & $\begin{array}{l}\text { External financial } \\
\text { services provider } \\
\text { systems integration, } \\
\text { Substitution } \\
\text { integrated internal } \\
\text { systems with a } \\
\text { compatible and } \\
\text { standardised external } \\
\text { system services }\end{array}$ \\
\hline $\begin{array}{l}\text { Phase 5: } \\
>2020\end{array}$ & $\begin{array}{l}\text { Hybrid } \\
\text { customer } \\
\text { channel }\end{array}$ & $\begin{array}{l}\text { Customer } \\
\text { processes }\end{array}$ & $\begin{array}{l}\text { External both } \\
\text { financial and non- } \\
\text { financial services } \\
\text { provider systems } \\
\text { integration, based on } \\
\text { platforms principle; } \\
\text { Replacing databases } \\
\text { with big data } \\
\text { analytics tools based } \\
\text { on artificial } \\
\text { intelligence solutions }\end{array}$ \\
\hline
\end{tabular}

Source: compilation by authors using [3] and [4]

The similar approach has been used by Consumers International [5] according to which financial technologies have gone through three major stages, and the first two stages until 2008 were characterized by the actions taken by commercial banks. It is assumed that the third stage started in 2008 can be described by the increased activity of non-banking institutions.

$\mathrm{Wu}$ emphasizes that today omni-channels have become cross-channels contending customer values to be in a constant contact with a company via multiple venues simultaneously. For instance, ewallets, which include not only payment, but also options to collect, store and spend loyalty points and other personal data.[4]

Fintech firms often begin activities with payment services. Afterwards, some of them expand into provision of credit, insurance, savings and investment products, which can be provided directly or in partnership with other financial institutions. 


\subsection{Fintech characteristics}

While the term is widely used, Fintech is rather complex as there are a variety of interpretations of its meaning. Fintech was used as the original name of the Financial Services Technology Consortium, a project by Citicorp in 1993 as an endeavour to overcome a reputation for resisting technological collaboration with outsiders [6].

According to the Fintech Regulatory Aspects Working Group the Fintech is considered as an elusive concept [7]. The definition is widely applied to institutions of a certain kind, quite often to startup companies, which are focused on delivering software based innovations in the financial services area. However, such a definition is likely to be incomplete because banks and other incumbents are also frequently applying similar technologies to upgrade services provided to customers. From this perspective, incumbents can reasonably claim that they are also "Fintech firms". The definition in some cases was applied to technologies underlying innovations (i.e. Fintech technologies). Nonetheless, the technologies can also be applied beyond financial services. Eventually, it is increasingly common to describe "Fintech" as the change in the financial services enabled by financial innovations.

Based on the World Economic Forum Fintech's prospects are highly appreciated, and the press presents these companies as "disruptive", "revolutionary" that will "destroy" traditional barriers and financial institutions [8].

Based on literature studies the authors conclude that there are two main streams of scientific literature regarding the Fintech concept.

The first one relates to Fintech as a firm, typically start-ups focused on delivering softwarebased innovation in the field of financial services or financial technology enabled companies [7]. Thus, describing Fintech firms as an alternative financial institution or BigTech (large Fintech firms), nonbanking companies, etc. Depending on the services provided there are different companies such as crowdfunding, e-money companies, InsurTech service providers and others which are forming new industries.

From this perspective the term Fintech sector has emerged and been used in scientific literature. Although the term "sector" was used in management science to describe related industries. The common understanding is that the financial sector covers all financial service providers, therefore, to separate the Fintech sector from the Financial sector from the authors point of view is meaningless.
Fintech firms provide similar or services as banks do, perhaps more efficiently because of greater use of technologies. For instance, as banks do, crowdfunding platforms transform savings into loans and investments [9]. This means that these authors distinguish Fintech firms from banks, so considering that Fintech firms are new entrants in the financial market operating alongside traditional financial services providers.

Based on this point of view, that there is a global assumption that financial technology enabled companies are not yet in a position to bring serious competition to credit institutions, and that these are stand-alone products that have been made more convenient. However, commercial banks have to look at products offered by Fintech firms, as some users find them more convenient.

The second stream of scientific literature emphasizes that Fintech is an application of latest technologies, e.g. artificial intelligence, blockchain, machine learning to deliver innovations in the financial sector, including in traditional banking, leasing and insurance companies leading to technology-based innovations. Thus, one author believes that "Fintech" is the use of technology to provide new and improved financial services. Part of the reasoning for the evolution of Fintech is that, while information technology helped decrease costs and increase usability, financial intermediation cost per unit has not changed much in over a century" [10]. Or Arner et al consider that "Fintech", a contraction of "Financial technology", refers to technology enabled financial solutions [3]. Vives understands Fintech as "the use of innovative information and automation technology in financial services. Szmigiera believes that Fintech relates to application of innovative technological solutions in the financial services industries. Mobile wallets and payments are the most influenced by Fintech, as more people, especially the younger generation, use the mobile banking applications [12].

Basel Committee on Banking Supervision defines Fintech as "technology based financial innovations, that can result in new business models, applications, processes or products associated with a material effect on financial markets and institutions and on the provision of services" [13].

According to the Financial Stability Board, Financial Technology is defined as a technologically enabled financial innovation, which could result in new business models, applications, processes or products with an associated material effect on financial markets and institutions and the provision of financial services [14]. 
According to Carmona et al, Fintech is considered to have an enormous potential in improving financial inclusion. [1] Fintech services possess capacity to provide more accessible and affordable financial services to wider groups of customers, in particular in the area of credits and payments.

Seeing Fintech as the application of technology to change financial services, disregarding its provider, is considered to be the most widely accepted definition nowadays [14].

Therefore, the authors will use two terms" Fintech firms" and "Fintech" as an application of latest technologies in the financial sector.

\subsection{The scope of Fintech and Fintech firms}

Based on different understanding of the term "Fintech " there are also differences in describing the scope of Fintech services. Following the most widely accepted definition of Fintech as the application of novel technologies in the financial sector, Deloitte defines Fintech as Information Technology solutions, which are dedicated to the financial sector both from traditional and nontraditional entities. Furthermore, eight subcategories of Fintech services are defined: (1) banking, (2) asset management and capital markets, (3) capital raising and personal finance, (4) payments, (5) data and analytics, (6) cybersecurity, (7) insurance and (8) other software [15].

According to Fintech Regulatory Aspects Working Group [7], in many cases, Fintech firms' activities do not result in new financial products or services, but rather applying new technologies used by the entities in their internal processes. Navaretti, et al suggest despite its wide scope, there are three main areas that Fintech covers - (1) execution of transactions (payments, clearing and settlement, digital currency, etc.), (2) fund management (deposits, loans, investment management, raising capital, etc.), (3) insurance.[9]

Based on Carmona et al the Fintech (firms authors) services could be classified as shown in Figure 1.
Fig.1. Classification of Fintech (firms)

\section{Daily financial services and personal financial management}

$$
\begin{aligned}
& \text {-Real time, P2P mobile payments, Mobile wallets, Budgeting, } \\
& \text { Comparison platforms, Foreign exchange }
\end{aligned}
$$

\section{Lending, saving and investment services}

$$
\begin{aligned}
& \text {-Deposits, saving accounts, automated advising, comparison } \\
& \text { websites, P2P lending, P2P investments }
\end{aligned}
$$

\section{Other financial services}

\section{- Cryptocurrencies, mining, data analytics, distributed ledger technologies, insurance comparisons}

Source: Compiled by authors based on [1]

The authors agree with Carmona et al. that "Fintech" is related to the application of latest technologies in the financial sector to deliver technology enabled solutions, both by traditional financial institutions and by alternative financial services providers for improving internal processes and delivering new financial products and services.

According to Arner et al "Fintech" is not confined to specific sectors or business models, but instead it covers the entire scope of services and products traditionally provided by the financial services industry.[3] At the same time according to Navaretti et al differently from banks, the Fintech firms use of information is rather based on big data, not that much on long term relationships. The access to services is typically decentralized through internet platforms while risk and maturity transformation is not carried out; lenders and borrowers or investors and investment opportunities are matched directly.[9]

In spite of the major amount of data available and formidable resources the industry has, most 
banks and credit institutions are still far from realising full potential from the big data. This outcome is caused by competing priorities, complexity of understanding what data to collect and how to use as well as a general lack of a coordinated vision. Further use of artificial intelligence, machine learning and other advanced analytic tools is expected to provide opportunities for greater personalization and channel optimization.

Fintech firms are often very specialized in a particular field. Some are pure P2P or clean mobile payment providers, while others operate as lending platforms (e.g., crowdfunding) to provide funding or investment opportunities. Still others focus primarily on new digital advisory and trading systems. Fintech firms often decide in favour of blockchain technology, which is expected to have yield many benefits:

a) reduced costs for identifying parties performing transactions.

b) economies of scale, collection and use of large amounts of data.

c) safer and cheaper transmission of information.

d) decreased verification costs [16].

As Frame et al pointed out [17], technological change generating financial innovations in banking, is having connotations for developments in Fintech firms. Non-intermediated peer-to-peer lending, cryptocurrencies and smart contracts are parts of customized financial services, which are assisted by technologies. Obviously, one of aspects of such a development that is somewhat unprecedented, is the extent to which such developments involve nonintermediated transactions.

Nowadays commercial banks still do have a greater market share and responsibility for economic events. Kelly et al recognize that commercial banks have several advantages such as brand, large customer base, wide product range, stable infrastructure, risk management experience, access to capital, licenses[18]. At the same time, it must be acknowledged that Fintech start-ups (firms) would not bear any responsibility for economic processes that would, for example, worsen a country's economy or have some other wider effect. In other words, Fintech start-ups (firms) are now more focused on improving certain services and making them more convenient or cheaper for customers rather than directly competing with banks. The competition in financial sector according to Mavlutova et al between Fintech firms of a similar profile, which is seen as the driving force for change [19].

\subsection{The role of Fintech firms in financial sector development}

Fintech firms boost competition in the financial markets, provide services, which are provided less efficiently by traditional financial institutions or not provided et all as well as expand the pool of service users. However, they do not typically replace banks in a majority of their key functions [9].

The authors underline that although Fintech as technology start-ups might face difficulties in utilizing banking services fully while providing the technology solutions, Fintech still create products where a user is not tied to a specific bank as a client. From the perspective of the development of traditional financial service providers, the current situation is increasingly dominated by the trend not to question the need for digital transformation and to recognize the significantly greater flexibility and innovation potential of Fintech firms.

Vives argues that potentially automated new digital technologies are capable of providing new and more cost-effective products in some parts of the financial industry, from lending to asset management, portfolio consulting and payment systems and emphasizes that big data and artificial intelligence are transforming the banking business and they have the potential to disrupt established financial intermediaries such as banks [11], [20]. The authors agree with Vives that banks conventionally focused on products and services, meanwhile newcomers proved to be more focused on customers. Therefore, Fintech are putting pressure on traditional business models employed by banks.

Two competitive advantages exploited banks, which are subject to erosion by Fintech are named to be:

1. banks have access to relatively cheap funding and direct or indirect insurance by governments

2. banks still have a relatively stable customer base, that can be upsold substantially [11].

It should be noted that some of the financial technology start-up solutions are designed to be integrated into banking processes or services (technological solutions for AML risk analysis, customer remote identification tools, etc.). Some of the innovations extend the ability for customers to combine traditional banking with functionality that comes from their business operations (such as shopping or selling). Of course, there are also duplicated services that Fintech firms can offer in a much more efficient way (more convenient and faster). However, the situation in recent years is 
characterized by the trend and opportunity for each of the notional "camps" in the financial services sector to develop in their niches and to cooperate more, complement each other than compete.

It is important to mention that investments in Fintech firms proved to be higher in countries with relatively weaker banking systems as well as in countries where interest on deposits is typically lower while loan margins are higher [9]. These implications indicate that the most promising opportunities for the fintech sector development can exist in the most financially developed countries, where a large part of the population already has an access to banking services and where banks enjoy a limited competitive environment, that enables them to generate higher income.

In the light of the above trends, the authors note that both traditional banks adopting a digital transformation dictation and Fintech firms have their own specifics in absorbing or creating new technologies that provide opportunities to develop or integrate more or less explicit knowledgeintensive technologies on a narrower spectrum, building on this basis its competitive advantage [21]. Such specificities imply specific and divergent competencies needs as well as an appropriate organizational structure.

Jünger and Mietzner based on the empirical study discovered that $31 \%$ of banks customer's survey respondents in Germany could imagine moving away from retail banks to Fintech firms, demonstrating that these newcomers are able to gain a significant market share from incumbents [22]. One of the driving factors behind the shift of market share toward Fintech firms is due to better customer satisfaction through better service offerings.

However, from a customer perspective, using these highly specialized services often requires a certain amount of financial expertise, which is one reason households with higher levels of financial knowledge are more likely to switch to Fintech firms.

On the other hand, study results reveal that the financial service price is not usual a criterion for taking a decision in favour of Fintech firms. It emphasises the convenience aspect, which is a more important differentiator than costs for traditionally oriented customers.

Nowadays, there is a global assumption that Fintech firms are not yet able to bring serious competition to banks, and that these are stand-alone products that have been made more convenient. Fintech firms are not engaged in the basic business of banks - attracting deposits and lending loans.
However, in the future, banks will have to look at products offered by Fintech firms, as some users will find them more convenient. True, today banks are still with much greater market share and responsibility for economic events [23].

The balance between stability and competition is central to Fintech firms and their regulation. The crucial question is whether and when Fintech firms will replace banks and other financial institutions and whether this replacement will improve the competitive process by increasing the efficiency of the financial market due to Fintech firms promise to reduce the costs of financial services and improving the well- being of their clients.

According to Gregory et al., commercial banks are faced with increasingly stringent regulatory and complex requirements in order to cope with business risks. To cope with these requirements, more effective governance and complex information technology infrastructure must be deployed [24]. Previously high entry barriers protected the financial market, and Fintech firms' entrance might lead to financial instability.

The growth of robotics, artificial intelligence, machine learning and other advanced analytical tools are providing opportunities to optimize business models in the financial sector both in commercial banking and Fintech firms. Nowadays, there are also Fintech firms that do not stop at the offer of one product. For example, Revolut Ltd has entered the market by offering payment cards, obtained a banking license in Lithuania and expanded its operations in the Baltic countries. This shows that Fintech firms have a vision to make banking services more accessible and/or cheaper for their customers.

The way commercial banks exploit both intangible and tangible assets, which also include competencies of managers and professionals, to develop an appealing customer-oriented service, is expected to play an important role in the competition [25]. 


\section{Research methodology and results}

\subsection{Research methodology}

To study the dynamics of changes in investments in Fintech by regions and by segments, let the variable $X_{i j}$ represent the amount of investments allocated to $i$ th region (segment) in $j$ th year. This value is regarded as follows:

$$
X_{i j}=\mu+\beta_{i}+\gamma_{j}+\varepsilon_{i j},
$$

where $\mu$ - mean of investments in Fintech;

$\beta_{i}$ - parameter specific to the $i$ th region (segment) and measures the discrepancy between the mean of investment for that region (segment) and the overall mean of investments;

$\gamma_{j}$ - parameter specific to the $j$ th year and measures the discrepancy between the mean of investment for that year and the overall mean of investments;

$\varepsilon_{i j}$ - a random variable which represents sample error.

As complete information on investments in Fintech is not available, sample data will be used in the study. Given sample data $x_{i j}$, the mean of investments in Fintech $\mu$ is estimated by overall sample mean $\overline{\bar{x}}$. $\beta_{i}$ is estimated as difference between mean investment allocated to the $i$ th region (segment) and overall mean, based on corresponding sample data $\left(\bar{x}_{i}-\overline{\bar{x}}\right)$. Similarly, $\gamma_{j}$ is estimated as difference between mean investment allocated to the $j$ th year and overall mean, based on corresponding sample data $\left(\bar{x}_{. j}-\overline{\bar{x}}\right)$. The error term is estimated by subtraction:

$$
\begin{aligned}
& \left(x_{i j}-\overline{\bar{x}}\right)-\left(\bar{x}_{i .}-\overline{\bar{x}}\right)-\left(\bar{x}_{. j}-\overline{\bar{x}}\right)= \\
& =x_{i j}-\bar{x}_{i .}-\bar{x}_{. j}+\overline{\bar{x}}
\end{aligned}
$$

Thus, based on sample data equation (1) can be rewritten as follows:

$$
\begin{aligned}
& \left(x_{i j}-\overline{\bar{x}}\right)=\left(\bar{x}_{i .}-\overline{\bar{x}}\right)-\left(\bar{x}_{. j}-\overline{\bar{x}}\right)+ \\
& +\left(x_{i j}-\bar{x}_{i .}-\bar{x}_{. j}+\overline{\bar{x}}\right)
\end{aligned}
$$

If both equation (3) are squared and summed for all observations, the result is as follows:

$$
\begin{aligned}
& \sum_{1}^{r} \sum_{1}^{c}\left(x_{i j}-\overline{\bar{x}}\right)^{2}=c \sum_{1}^{r}\left(\bar{x}_{i .}-\overline{\bar{x}}\right)^{2}-r \sum_{1}^{c}\left(\bar{x}_{. j}-\overline{\bar{x}}\right)^{2}+ \\
& +\sum_{1}^{r} \sum_{1}^{c}\left(x_{i j}-\bar{x}_{i .}-\bar{x}_{. j}+\overline{\bar{x}}\right)^{2}
\end{aligned}
$$

This equation expresses the total sample variability of the observations about their overall mean as the sum of variabilities due to differences among regions (segment), differences among years, and error, respectively. For analysis of these sums of squares two-way analysis of variance will be used, since data are categorized in two ways, according to regions (segments) and years. The authors assume that the error terms $\varepsilon_{i j}$ are independent of one another and have the same variance, and normally distributed. Then, a test of significance level $\alpha$ of the null hypothesis:

$$
H_{0}: \beta_{i}=0 \text { for all } i
$$

is provided by following decision rule:

reject $H_{0}$ if:

$$
\frac{M S C}{M S E}>F_{c r i t},
$$

where

$$
\begin{aligned}
M S C & =\frac{c \sum_{1}^{r}\left(\bar{x}_{i .}-\overline{\bar{x}}\right)^{2}}{r-1} \\
M S E & =\frac{\sum_{1}^{r} \sum_{1}^{c}\left(x_{i j}-\bar{x}_{i .}-\bar{x}_{. j}+\overline{\bar{x}}\right)^{2}}{(r-1) *(c-1)}
\end{aligned}
$$

$F_{c r i t}$ is value of $F$ distribution with numerator degrees of freedom $v_{1}$ and denominator degrees of freedom $v_{2}$. A test of significance level $\alpha$ of the null hypothesis:

$$
H_{0}: \gamma_{j}=0 \text { for all } j
$$

is provided by following decision rule:

reject $H_{0}$ if:

$$
\frac{M S R}{M S E}>F_{\text {crit }},
$$

where

$$
M S R=\frac{r \sum_{1}^{c}\left(\bar{x}_{. j}-\bar{x}\right)^{2}}{c-1} .
$$




\subsection{Research results and discussion}

Global investment in Fintech has grown rapidly over the past decade, from US\$ 2-3 billion in the first two years of the decade to more than US $\$ 53$ billion in 2018-2019.

The Figure 2 confirms these statistics and shows that there have been changes in the regional distribution of investment, with North America (8590\%) dominating in the first years of the decade, and Asia and the Pacific accounting for more than a third and Europe for more than 20\% of total investment in recent years.

Fig.2. Investments in Fintech ventures by regions, $2010-2019$

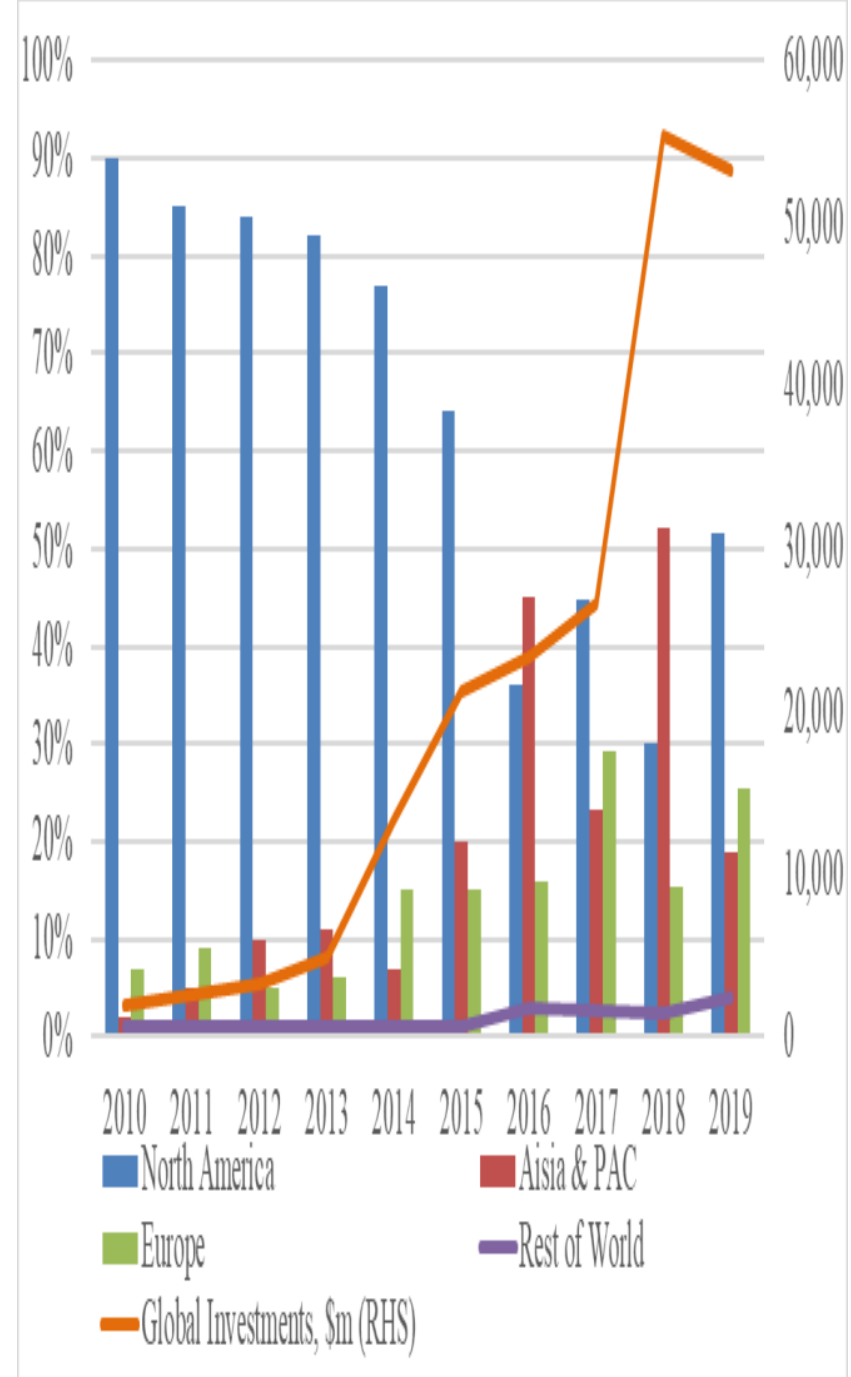

Source: compiled by the authors using CB Insights data [26]

To make sure that these changes are statistically significant, the following hypothesis were tested $\# 1$ : there is a statistically significant difference in between investments in Fintech firms by regions and years.

Prior to performing analysis of variance, the assumptions regarding distribution of residuals was tested with chi-squared test. As computed $\chi^{2}(28,046)$ was smaller than $\chi_{\text {crit }}^{2}(40,113)$ at confidence level $95 \%$, the authors conclude that residuals distributions differences by regions from normal distribution aren't statistically significant. For homogeneity of variance Levene's test [27] was applied:

$$
F=\frac{N-k}{k-1} \frac{\sum_{1}^{k}\left(\bar{d}_{i .}-\bar{d}_{. .}\right)^{2}}{\sum_{1}^{k} \sum_{i}^{n_{i}} n_{i}\left(d_{i j}-\bar{d}_{i .}\right)^{2}},
$$

where $\quad d_{i j}=\left|x_{i j}-\bar{x}_{i}\right|, i=1, \ldots k, j=1, \ldots n_{i}$. As computed statistic $F(2,023)$ was smaller than $F_{\text {crit }}(2,866)$ at confidence level $95 \%$, authors can conclude that the variances differences by regions aren't statistically significant. And as computed statistic $F(1,798)$ was smaller than $F_{\text {crit }}(2,211)$ at confidence level $95 \%$, the authors conclude that the variances differences by years aren't statistically significant.

As the main assumptions were confirmed, for hypothesis testing two-factor analysis of variance with confidence level $95 \%(\alpha=0,05)$ was used and the results are shown in Table 2.

Table 2. Two factor ANOVA test output for Hypothesis \#1 for testing differences in investment in Fintech by regions and years

\begin{tabular}{|l|r|r|r|c|c|c|}
\hline Source of & $S S$ & $d f$ & $M S$ & $F$ & $p$-value & $F_{\text {crit }}$ \\
\hline Variation & & & & & & \\
\hline Regions & 462,4 & 3 & 154,1 & 6,926 & $<0,001$ & 2,960 \\
\hline Years & 898,9 & 9 & 99,9 & 4,488 & $<0,001$ & 2,250 \\
\hline Error & 600,9 & 27 & 22,3 & & & \\
\hline Total & 1962,2 & 39 & & & & \\
& & & & & & \\
\hline
\end{tabular}

Source: computed by authors using CB Insights data 
As Table 2 reflects both computed $F \gg F_{\text {crit }}$ thus the authors conclude that there is strong evidence about statistically significant difference between investments allocated to Fintech firms by regions and vintage. These conclusions are supported by low $p$-values $(p<0,001)$. Thus, hypothesis \#1 is proven.

Contemporary statistics data analysis also indicates different trends in investments in various Fintech segments by years: in the first half of the decade payments (46\%) and loans (22\%) dominated, while in the last five years the share of loans has increased to $27 \%$, the share of wealth management has more than doubled (14\%) and the share of insurance has increased by two thirds $(10 \%)$ as shown in Figure 3.

Fig.3. Investments allocated to Fintech segments, $2010-2019$

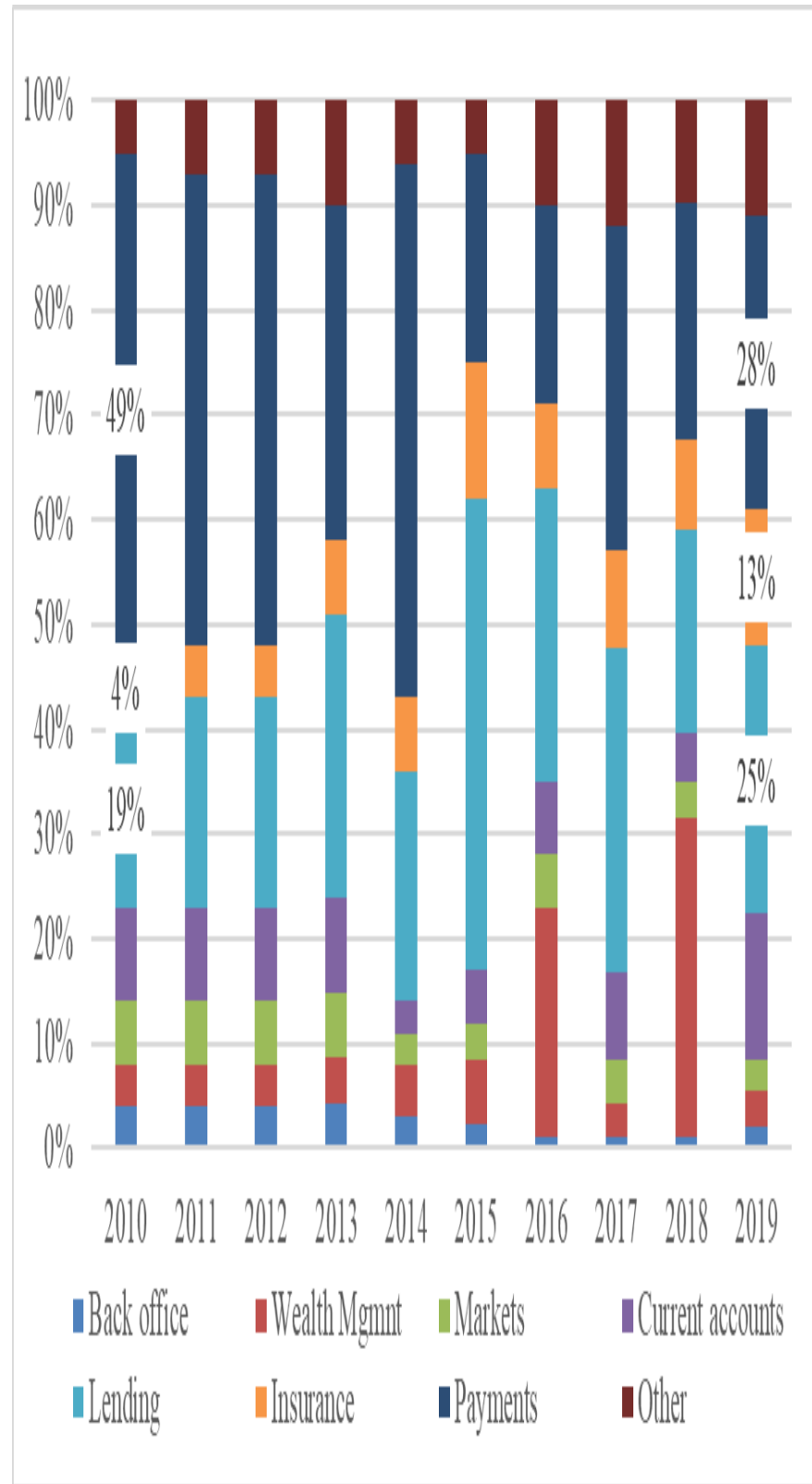

Source: compiled by the authors using CB Insights data [26]

Hypothesis statement \#2: there is a statistically significant difference between investments allocated to Fintech segments by years.

Prior to performing analysis of variance, the assumptions regarding distribution of residuals was tested with chi-squared test. As computed $\chi^{2}$ $(58,188)$ was smaller than $\chi_{\text {crit }}^{2}(82,529)$ at confidence level 95\%, the authors conclude that residuals distributions differences from normal distribution aren't statistically significant. For homogeneity of variance Levene's test was applied. As computed $F(1,678)$ was smaller than $F_{\text {crit }}$ $(2,140)$ at confidence level $95 \%$, the authors came to conclusion that the variance differences by segments aren't statistically significant. And as 
computed statistic $F(1,869)$ was smaller than $F_{\text {crit }}$ $(2,017)$ at confidence level $95 \%$, the authors believe that the variances differences by years aren't statistically significant.

As main assumptions were confirmed, to test hypothesis two-factor analysis of variance with confidence level 95\% $(\alpha=0,05)$ was used and the results are shown in the following Table 3.

Table 3. Two factor ANOVA test output for Hypothesis \#2 for testing differences in investment allocated to Fintech segments by years

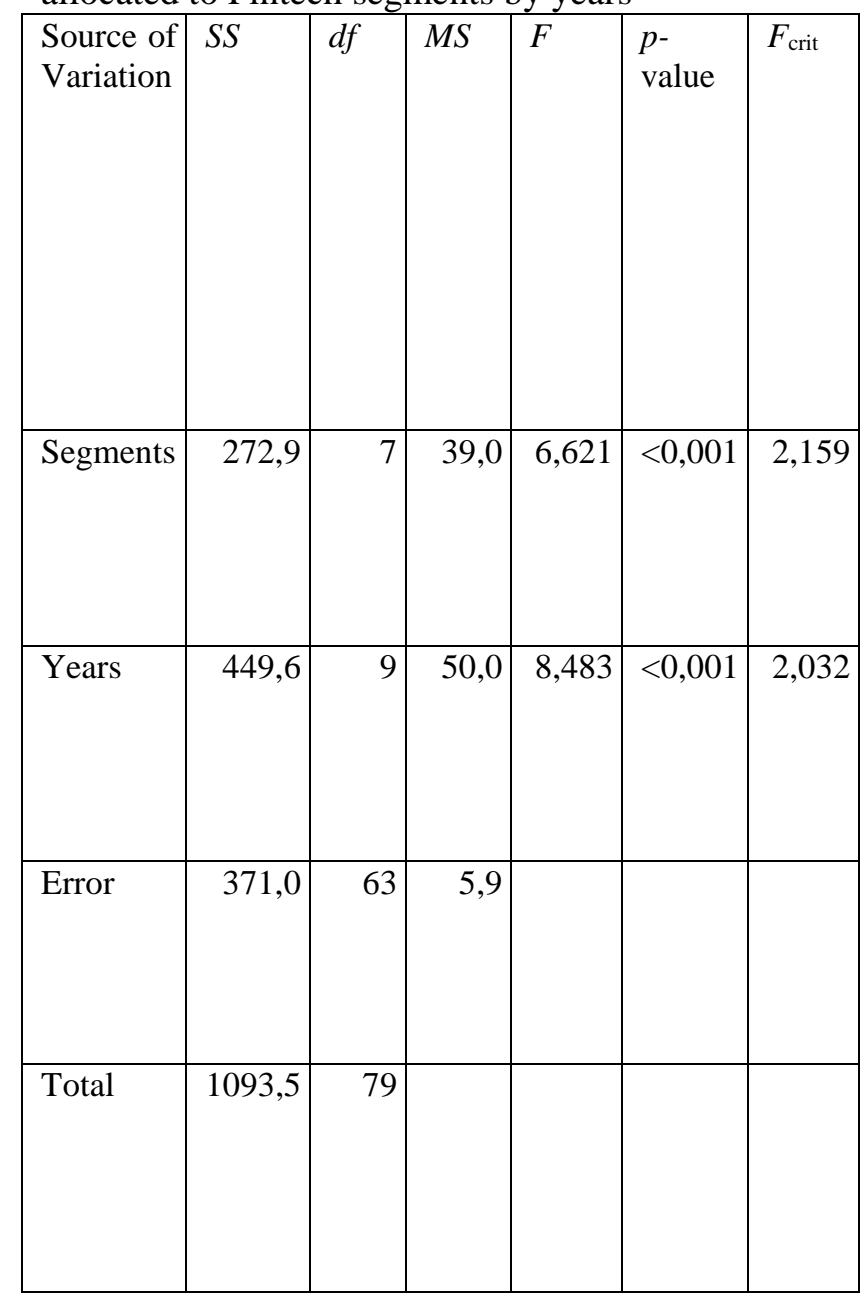

Source: computed by authors using CB Insights data

As Table 3 shows both computed $F \gg F_{\text {crit }}$ the authors conclude that there is clear evidence about statistically significant difference in between investments allocated to Fintech services by years. These conclusions are supported by very low $p$ values $(p<0,001)$. Thus hypothesis $\# 2$ is proven.

The authors came to conclusion that there is strong evidence about statistically significant difference between investments allocated to Fintech firms by regions and vintage. There is a clear evidence about statistically significant differences between investments allocated to Fintech services by years.

\subsection{Discussion}

Various studies, e.g. research conducted by Navaretti et al [9] showed a relationship between the investment amount in the Fintech and specific characteristics of national banking systems. For instance, investments in Fintech proved to be higher in financially developed countries while the use of electronic payments is more common in countries, where there is a large percentage of the population with accounts open at different financial institutions [22].

The authors share the view of Anagnostopoulos and Drasch et al., believing that Fintech reached main channels of commercial banks. Meanwhile, the banks are struggling with further innovation and face high chances to loose to Fintech firms, which offer capabilities enabled by technologies and disrupt conventional value propositions [28], [29].

The authors agree with Kotarba [30] and Supe et al [31] that digital transformation influenced changes in the financial sector, Mavlutova at el [19] underlined that its main driving force is the availability of data due to technology development combined with modern big data analytical resources that provide high quality products for customers. Kelly at el emphasize that commercial banks still have several advantages [18], Vives argues that banks have traditionally focused on products, while new entrants are more focused on customers[11]. The authors conclude Fintech competitors are putting pressure on the traditional business model of banks, however draw attention in this regard to the fact that this relationship involves a paradox, given that traditional banks still base their business on customer loyalty and client relationships, while Fintech is less focused on personalizing such relationships. In fact, customer orientation based on user experience is an ICT development mega-value proposition that is a supply grounded on the calculation of neuron networks in a big data environment. Some similar studies can be found in [32] and [33]. 


\section{Conclusions}

During the study, the authors came to the conclusion, that the application of new technologies is topical for companies, especially those working in the financial sector. However, the scientific and professional literature lacks a common understanding of the Fintech concept. There are a variety of interpretations of the term "Fintech" meaning .

The authors suggest using two terms" Fintech firms" and "Fintech" as an application of latest technologies in the financial sector. The authors suggest to consider the phases of financial technologies development differing by strategy focus, organization focus and systems focus based on Arner et al [3] and $\mathrm{Wu}$ [4]

An analysis of the Fintech development and main estimates by experts demonstrate that these companies will lead to increased competition in the financial markets. Fintech firms are widely represented in the financial market thus becoming competitors for the banks. Although Fintech as technology start-ups may not be able to fully utilize banking services in their technology solutions, they still create products where the user is not tied to a particular bank as a customer.

The Fintech firms are not homogenous and can be classified as those who provide a daily financial and personal financial management services, providers of lending, saving and investment services and other financial services providers, e.g. data analysis, distributed ledger technologies, etc.

Fintech firms mostly introduce new services and in a much more efficient way the services and products that traditional financial institutions offer, but at the same time Fintech companies do not threaten the core functions of the commercial banks.

The authors conclude that partnerships between traditional financial institutions and Fintech are mutually beneficial. Through partnerships both parties can scale up business and reach a larger customer base, enhance their competitive position and improve product efficiency.

Provided the size of organizations, the financial sector, in particular Fintech in today's world is the main user of new information and communication technologies related to business process digitalization, automation and the use of artificial intelligence. Main opportunities for the development of the financial sector are supposed to be digitalization and innovation.
Contemporary technologies linked to digitalization of business processes, automation and the use of artificial intelligence demand the creation of different business models for companies operating in the financial sector. In many countries, where large rural populations have traditionally been underserved by incumbents, these customer segments can now be covered by digital-oriented providers.

\section{Acknowledgement}

This paper was supported by the BA School of Business and Finance Internal Research Project "The Assessment of Competence Management in the Latvian Financial Sector".

\section{References:}

[1] Carmona, A.F., Lombardo, A.G-Q., Pastor, R.R., Quiros, C.T., Villar Garcia, J.P., Ramos Munoz, D. \& Castejon Martin, L., Competition issues in the area of financial technology (Fintech), Policy Department for Economic, Scientific and Quality of Life Policies of the European Parliament, 2018.

[2] Marous, J., Retail Banking Trends and Predictions 2019, LLC Issue Vol.260, 2017.

[3] Arner, D. W., Barberis, J. \& Buckley, R.P., The Evolution of Fintech: A New Post-Crisis Paradigm?, University of Hong Kong Faculty of Law Research Paper, Vol.2015/047, 2015.

[4] Wu, P. S., Fintech trends relationships research: A bibliometric citation meta-analysis, Proceedings of the 17th International Conference on Electronic Business, ICEB, Dubai, UAE, 2017, pp. 99-105.

[5] Bates, R., Banking on the future: an exploration of fintech and the consumer interest, A Report for Consumers International, 2017.

[6] A Brief History of Fintech, Online. Available: http://www.theiyerreport.com/wpcontent/uploads/2017/07/A-Brief-Timeline-ofFintech.pdf?source $=$ post

[7] Fintech Regulatory Aspects Working Group, Key Aspects around Financial Technologies and Regulation Policy report, 2019.

[8] World Economic Forum, Beyond Fintech: A Pragmatic Assessment of Disruptive Potential In Financial Services, 2017.

[9] Navaretti, G.B., Calzolari, G., MansillaFernandez, J.M. \& Pozzolo, A.F., FinTech and Banks: Friends or Foes?, European Economy, Vol.2, No.9-3, 2017. 
[10] Thakor, A. V., Fintech and banking: What do we know?, Journal of Financial Intermediation, Vol.41, No.100833, 2020.

[11] Vives, X., Competition and stability in modern banking: A post-crisis perspective, International Journal of Industrial Organization, Vol.64, No.55-69, 2019.

[12] Szmigiera M., Number of Fintech startups worldwide 2019, Online, Available: https://www.statista.com/statistics/893954/num ber-fintech-startups-by-region/

[13] Basel Committee on Banking Supervision. Sound Practices Implications of fintech developments for banks and bank supervision, Online, 2018, Available: https://www.bis.org/bcbs/publ/d431.pdf

[14] Financial Stability Board. Monitoring of FinTech, Online, 2017, Available: https://www.fsb.org/work-of-the-fsb/policydevelopment/additional-policyareas/monitoring-of-fintech/

[15] Deloitte, Fintech in CEE. Charting the course for innovation in financial services technology, Online, 2016, Available: https://www2.deloitte.com/content/dam/Deloitt e/global/Documents/About-Deloitte/centraleurope/ce-fintech-in-cee-region-2016.pdf

[16] Hadad, S., \& Bratianu, C. Dematerialization of banking products and services in the digital era, Management \& Marketing. Challenges for the Knowledge Society, Vol.14. No.3, 2019, pp. 318-337.

[17] Frame, W. S., Wall, L.D., White, L.J., Technological change and financial innovation in banking: Some implications for fintech, Working paper, Federal Reserve Bank of Atlanta, Atlanta, GA, No.2018-11, 2018.

[18] Kelly, S., Ferenzy, D. \& McGrath, A., How financial institutions and fintechs are partnering for inclusion: Lessons from the frontlines, Center for Financial Inclusion at Accion, 2017.

[19] Mavlutova, I., Volkova, T., Spilbergs, A., Natrins, A, Arefjevs, I \& Miahkykh, I., Financial Sector Transformation in the Era of Digitalization, Journal Studies of Applied Economics (Estudios de Economía Aplicada), Vol.38 No.3(1), 2020, pp.1-11.

[20] Vives, X. The impact of FinTech on banking. European Economy, Vol.2, 2017, pp.97-105.

[21] Lee, I., \& Shin, Y. J. Fintech: Ecosystem, business models, investment decisions, and challenges, Business Horizons, Vol.61. No.1, 2018, pp. 35-46.
[22] Jünger, M., \& Mietzner, M. Banking goes digital: The adoption of FinTech services by German households, Finance Research Letters, Vol.34, No.101260, 2020.

[23] Mavlutova, I., \& Volkova, T. Digital Transformation of Financial Sector and Challenges for Competencies Development. 7th International Conference on Modeling, Development and Strategic Management of Economic System (MDSMES 2019), Atlantis Press, 2019.

[24] Gregory, R. W., Kaganer, E., Henfridsson, O. \& Ruch, T.J., IT Consumerization and the Transformation of IT Governance, MIS Quarterly, Vol.42, No.4, 2018, pp.1225-1253.

[25] Chen, L., Danbolt, J., Holland, J., Rethinking bank business models: the role of intangibles, Accounting, Auditing \& Accountability Journal, 2014.

[26] CB Insight 2020, Online, Available: https://www.cbinsights.com/research/report/fint ech-trends-q4-2019/

[27] Levene, H. In Contributions to Probability and Statistics: Essays in Honor of Harold Hotelling, I. Olkin et al. eds., Stanford University Press, 1960, pp. 278-292.

[28] Anagnostopoulos, I., Fintech and regtech: Impact on regulators and banks, Journal of Economics and Business, Vol.100, 2018, pp.725.

[29] Drasch, B. J., Schweizer, A., Urbach, N., Integrating the 'Troublemakers': A taxonomy for cooperation between banks and fintechs, Journal of Economics and Business, Vol.100, 2018, pp.26-42.

[30] Kotarba, M., New factors inducing changes in the retail banking customer relationship management (CRM) and their exploration by the FinTech industry, Foundations of management, Vol.8, No.1, 2016, pp.69-78.

[31] Supe, L., Natrins, A. \& Mikelsone, E., Information Technology competency management in the financial sector: literature review, Rural Development 2019, Vol.2, No.268, 2019. 
[32] Pham Tuan Anh, Dinh Tran Ngoc Huy, Bui Thi Thu Loan, Analysis of a Financial Model for Converting Industrial Waste Tires into Clean Energy for Environment Protection - A Model in Developing Countries, WSEAS Transactions on Environment and Development, pp. 447454, Volume 15, 2019,

[33] Tina Kartika, Teguh Budirahardjo, Nanda Utaridah, Urfina Frizka, Henni Kusumastuti, An Investigation of Behavior and Public Opinion, Pros-Cons of Forest Encroachment Sustainability Issues in BBSNP of Tanggamus District, Indonesia, WSEAS Transactions on Environment and Development, pp. 22-31, Volume 15, 2019

\section{Creative Commons Attribution License 4.0} (Attribution 4.0 International, CC BY 4.0)

This article is published under the terms of the Creative Commons Attribution License 4.0

https://creativecommons.org/licenses/by/4.0/deed.en US 